\title{
Abundance and diversity of dragonflies four years after the construction of a reservoir
}

\author{
João Ânderson Fulan ${ }^{1, *}$, Rui Raimundo ${ }^{2}$, Diogo Figueiredo ${ }^{2}$ and Manuela Correia ${ }^{2}$ \\ ${ }^{1}$ Federal University of Amazonas, Brazil, Campus of Humaitá \\ ${ }^{2}$ University of Évora, Portugal, Campus of Mitra \\ * Corresponding author: joaofulan@uevora.pt
}

Received: 27/12/08

Accepted: 26/3/10

\begin{abstract}
Abundance and diversity of dragonflies four years after the construction of a reservoir

Few studies have investigated the impacts of river impoundments on reservoir constructions. Reservoir construction deeply changes dragonflies' habitat structures, especially in relation to shoreline vegetation. This study investigated the effects of the impoundment of the Guadiana River and its tributaries on dragonflies four years after the construction of a reservoir. A total of 17 dragonfly species (11 Zygoptera and ten Anisoptera), representing six families, were recorded in 21 sites in the years 1999 and 2003. Aeshna mixta, Coenagrion caerulescens, Coenagrion scitulum, Sympetrum foscolombei, Sympetrum meridionale and Sympetrum striolatum were sampled just before the impoundment took place, and Anax parthenope, Onychogomphus forcipatus, Orthetrum coerulescens, Trithemis annulata, Platycnemis acutipennis and Platycnemis latipes were recorded only after the construction of the reservoir. We concluded that the construction of the Alqueva Reservoir four years earlier did not change the dragonfly species richness, possibly because of species overlap, but that the species composition was modified. Changes in marginal vegetation may have been important to new species compositions.
\end{abstract}

Key words: Dragonfly, reservoir, vegetal cover.

\section{RESUMEN}

\section{Diversidad y abundancia de libélulas (Odonata) cuatro años después de la construcción de la Represa de Alqueva}

Pocos estudios han analizado el impacto de la detención del flujo de la ribera por construcción de una represa. La construcción de represas cambia fuertemente el hábitat de las libélulas, especialmente, la cobertura vegetal y cantidad de agua próxima al margen. En este trabajo se estudió el efecto de la detención del flujo de la ribera y del subafluente del río Guadiana, sobre el número y diversidad de libélulas, cuatro años después del impacto. La correspondencia canónica mostró que la ocurrencia de Coenagrion lindeni está positivamente influenciada por la presencia de piedras en el margen. C. caerulescens fue encontrada en sitios con elevada cantidad de piedras y poca cantidad de agua. Nosotros concluimos que no hubo reducción en el número de especies tras la construcción de la represa pero la diversidad fue más baja y la composición de las especies fue diferente. Aeshna mixta, Coenagrion caerulescens, Coenagrion scitulum, Sympetrum foscolombei, Sympetrum meridionale y Sympetrum striolatum fueron encontradas solamente antes de la construcción de la represa mientras que Anax parthenope, Onychogomphus forcipatus, Orthetrum coerulescens, Trithemis annulata, Platycnemis acutipennis $y$ Platycnemis latipes fueron encontradas solamente después de la construcción de la misma.

Palabras clave: Libélulas, embalse, cobertura vegetal. 


\section{INTRODUCTION}

Reservoirs are hybrid artificial systems of water storage (Thornton et al., 1990; Gopal et al., 1981). The formation of a hybrid system, according to some authors, alters the physical and chemical characteristics of the water as the current speed and oxygen concentration modify the marginal vegetation on the river's shoreline. These changes in the habitat directly affect the aquatic organisms. Due to this, many studies have been carried out to assess reservoir impacts on biota such as the dragonfly.

The dragonfly is a key predator among insects, recorded frequently in aquatic ecosystems, such as streams, rivers, ponds and lakes (Corbet, 1999). In recent years, it has been used as an ecological tool to assess the integrity of aquatic ecosystems because of its high sensitivity to human disturbances, such as reservoir constructions (Samways \& Steytler, 1996; Chovanec \& Raab, 1997; Chovanec, 2000; Chovanec \& Waringer, 2001; Clausnitzer, 2003). Many authors showed that lotic damming modified the marginal vegetation and thus the composition of dragonfly species (Cannings \& Cannings, 1998; Suh \& Samways, 2005). Marginal vegetation provides shelter and especially foraging sites for dragonflies (Corbet, 1999; Corbet, 2006). Some species with a longer pre-reproductive period can be negatively affected because they need a higher quantity of resources to conclude their life cycle (Kadoya et al., 2008). However, there are reports of highly tolerant species, such as Brachythemis leucosticte (Samways \& Grant, 2007) and Crocothemis erythraea (Sato \& Riddiford, 2007). Therefore, the construction of a reservoir can favour more resistant species and reduce dragonfly species with higher sensitivity to the impacts of their habitat.

The objective of the present study was to assess 21 sites in a reservoir that was created four years earlier to determine the changes that had taken place, document the marginal vegetation changes and show how these have affected the assemblage of dragonflies over time.

\section{MATERIALS AND METHODS}

\section{Study area}

The study site was the Guadiana River and its tributaries in southern Portugal, $38^{\circ} 08^{\prime} \mathrm{N}, 7^{\circ} 35^{\prime} \mathrm{E}$ (Fig. 1a). The impoundment of the Guadiana River and its tributaries created the Alqueva Reservoir (Fig. 1b). The Alqueva Reservoir has a Mediterranean climate with hot dry summers and humid cold winters (annual rainfall of $400 \mathrm{~mm}$ ). The sites were visited in 1999 and 2003. After sampling in 1999, a strong human disturbance was noted by the removal of the vegetal cover (shrubby, shrubby and arboreous, and riparian cover) for the construction of the Alqueva Reservoir.

\section{Dragonfly sampling}

Twenty-one sampling sites were used during the springs of 1999 and 2003, making three replicates during the peak flight period of the species known to occur in the area (Suh \& Samways, 2001). Adult male Odonata were recorded by walking for $20 \mathrm{~m}$ around the shoreline. Only males were counted because females and prereproductive- age individuals are not always in close association with the water, and their identification can be uncertain and unreliable. When the identification of males was difficult, the individual was captured, identified with a hand lens and then released. The following keys were used for identifying males: Askew (2004) and D'Aguilar \& Dommanget (1998). The collected specimens were stored in ethyl-alcohol $(70 \%)$.

\section{Environmental variables}

Twenty-one circle areas (400 $\mathrm{m}$ in diameter) were delimited. The diameter of $400 \mathrm{~m}$ was used to avoid the superposition of the sampling sites. The centre of the circle was the sampling site. Six environmental variables were measured (hectare) in each area: arboreous, shrubby, herbaceous, 


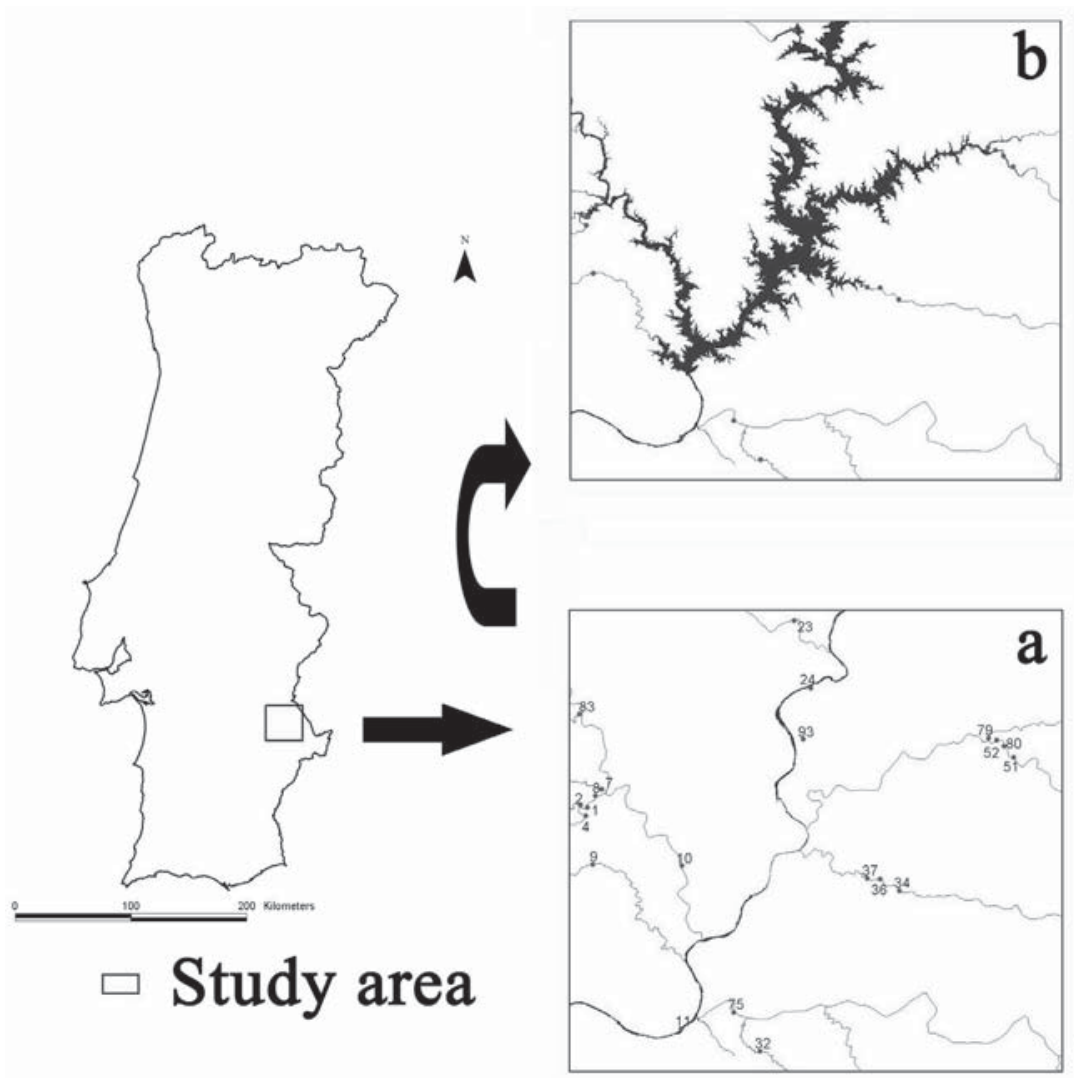

Figure 1. Map of the study area with numbers indicating the 21 study sites. (a) the Guadiana River and its tributaries and (b) the Alqueva Reservoir. Mapa de la zona de estudio con indicación de las 21 localidades estudiadas. (a) El río Guadiana y sus afluentes, y (b) el embalse de Alqueva.

shrubby and arboreous, riparian and water, according to the following criteria:

1. Arboreous: cork oak, olive and holm oak.

2. Shrubby: bushes.

3. Herbaceous: grassy and grazing ground.

4. Shrubby and arboreous: cork oak, olive and holm oak in association with bushes.

5. Riparian: marginal forest.

6. Water: Guadiana River and its tributaries.

To assess the vegetal cover, Idrisi32, module CROSSTAB software was used. The CROSSTAB module allows a comparison between the picture and the vegetal cover by the number of pixels. The result is a table with a number of pixels and many combinations with pictures and measures of association.

\section{Statistical analyses}

Canonical correspondence analyses (CCA) (Ter Braak, 1986), using CANOCO for Windows, were used to relate the species abundance data to environmental variables. Data on dragonfly species were subjected to an analysis of diversity using the species richness Shannon-Wiener Information Index (Shannon \& Weaver, 1963).

\section{RESULTS}

A total of 17 dragonfly species (11 Zygoptera and ten Anisoptera) representing six families were recorded at 21 sites during the years 1999 and 
Table 1. Abundance of species of dragonflies in the Alqueva Reservoir for the 1999-2003 period expressed as number of individuals and habitat type, according Askew (1988). Abundancia de libélulas en el embalse de Alqueva para el periodo $1999-2003$ expresado como número de individuos y tipo de hábitat, según Askew (1988).

\begin{tabular}{|c|c|c|c|}
\hline \multirow{2}{*}{$\begin{array}{l}\text { Species } \\
\text { Anisoptera }\end{array}$} & \multicolumn{2}{|c|}{ Abundance } & \multirow[t]{2}{*}{ Habitat } \\
\hline & 1999 & 2003 & \\
\hline \multicolumn{4}{|l|}{ Aeshnidae } \\
\hline Aeshna mixta (Latreille, 1805) & 4 & 0 & Ponds and lakes \\
\hline Anax parthenope (Sélys, 1839) & 0 & 1 & Ponds and lakes \\
\hline \multicolumn{4}{|l|}{ Gomphidae } \\
\hline Onychogomphus forcipatus (Linnaeus, 1758) & 0 & 1 & Rivers and lakes \\
\hline Paragomphus genei (Sélys, 1841) & 14 & 21 & Rivers \\
\hline \multicolumn{4}{|l|}{ Libellulidae } \\
\hline Crocothemis erythraea (Brullé, 1832) & 4 & 9 & Ponds \\
\hline Orthetrum coerulescens (Fabricius, 1798) & 0 & 1 & Ponds \\
\hline Sympetrum fonscolombei (Sélys, 1840) & 2 & 0 & Streams \\
\hline Sympetrum meridionale (Sélys, 1841) & 1 & 0 & Ponds \\
\hline Sympetrum striolatum (Charpentier, 1840) & 15 & 0 & Ponds \\
\hline Trithemis annulata (Palisot de Beauvois, 1807) & 0 & 9 & Rivers \\
\hline \multicolumn{4}{|l|}{ Zygoptera } \\
\hline \multicolumn{4}{|l|}{ Coenagrionidae } \\
\hline Cercion lindeni (Sélys, 1840) & 4 & 10 & Rivers \\
\hline Coenagrion caerulescens (Fonscolombe, 1838) & 1 & 0 & Streams \\
\hline Coenagrion scitulum (Rambur, 1842) & 1 & 0 & Ponds \\
\hline Ischnura graellsi (Rambur, 1842) & 44 & 73 & Ponds \\
\hline \multicolumn{4}{|l|}{ Lestidae } \\
\hline Lestes viridis (Vander Linden, 1825) & 42 & 34 & Ponds and lakes \\
\hline \multicolumn{4}{|l|}{ Platycnemidae } \\
\hline Platycnemis acutipennis (Sélys, 1841) & 0 & 1 & Rivers \\
\hline Platycnemis latipes (Rambur, 1842) & 0 & 5 & Streams and rivers \\
\hline Total abundance & 174 & 165 & \\
\hline Total number of species & 11 & 11 & \\
\hline Diversity índex ( Shannon-Wiener) & 2.63 & 2.40 & \\
\hline
\end{tabular}

2003 (Table 1). We recorded in 1999 a total of 174 individuals representing 11 species (six Anisoptera species and five Zygoptera species). I. graellsi, C. caerulescens and $L$. viridis were the most abundant dragonfly species in 1999 . We recorded in 2003 a total of 165 individuals representing 11 species (six Anisoptera species and five Zygoptera species). The dragonfly species that were most abundant in 2003 were I. graellsi, L. viridis and P. genei.

The Shannon-Wiener diversity index in 1999 and 2003 was 2.63 and 2.40, respectively (Table 2).

\section{Ordination with environmental variables}

The results of the Monte Carlo permutation test based on the first eigenvalue and the sum of all of the canonical eigenvalues showed the significance of the first ordination axis and that of all of the canonical axes together $(F=0.388, P<0.01$; $F=2.849, P<0.01$, respectively), showing that the relationship between the species and the environmental variables was statistically significant. The eigenvalues were 0.702 for the first axis and 0.366 for the second axis.

A. mixta, C. scitulum, I. graellsi, L. viridis, S. fonscolombei, S. meridionale and S. striolatum were located near the centre of the ordination diagram, showing characteristics of typically ubiquitous species. The occurrence of $C$. lindeni was positively influenced by the quantity of water and negatively influenced by the presence of stones in the shoreline. C. caerulescens were found in conditions with high stone covers and low quantities 
Table 2. Summary of the shoreline characteristics measured for each of the 21 studied sites included in the Canonical Correspondence Analysis (CCA). Bodies of water were categorised based on size: large (15 m or more in width); medium (from $5 \mathrm{~m}$ but less than $15 \mathrm{~m}$ in width) and small (less than $5 \mathrm{~m}$ in width). Shade, stones and submerged macrophytes were measured in cover percentages. Resumen de las características del litoral medidos en cada una de las 21 localidades estudiadas, que se han incluido en el Análisis Canónico de Correspondencias (CCA). Cada localidad fue categorizada por su tamaño: grandes (igual o mayores de 15 de anchura); medias (de $5 \mathrm{~m}$ pero menos de $15 \mathrm{~m}$ de anchura) y pequeñas (menos de $5 \mathrm{~m}$ de anchura). El sombreado, las piedras y los macrófitos sumergidos se midieron como el tanto por ciento de cobertura.

\begin{tabular}{lll}
\hline \multicolumn{2}{c}{ Shoreline characteristic } & Sites \\
\hline \multirow{3}{*}{ Shade } & $<25 \%$ & $1-2-8-9-11-24-34-51-52-75-80-93$ \\
& $25-50 \%$ & $32-36-37-79-83$ \\
& $>50 \%$ & $4-7-10-23$ \\
\hline \multirow{2}{*}{ Stones } & $<25 \%$ & $7-9-11-23-32-36-37$ \\
& $25-50 \%$ & $1-8-10-24-51-52-79$ \\
& $>50 \%$ & $2-4-34-75-80-83-93$ \\
\hline \multirow{2}{*}{ Submerged macrophytes } & $<25 \%$ & $1-2-4-10-23-24-37-51-52-79-80-83-93$ \\
& $25-50 \%$ & $7-8-9-11-32-34-36-75-$ \\
\hline Small sized canals & $>50 \%$ & $1-2-4-7-8-9-10-23-32-34-36-37-51-52-79-80-83-93$ \\
\hline Medium sized canals & $24-75$ \\
\hline Large sized canals & 11 \\
\hline
\end{tabular}

of water. All dragonfly species recorded in this study showed no correlation with shade percentage, suggesting an affinity for sunshine (Fig. 2).

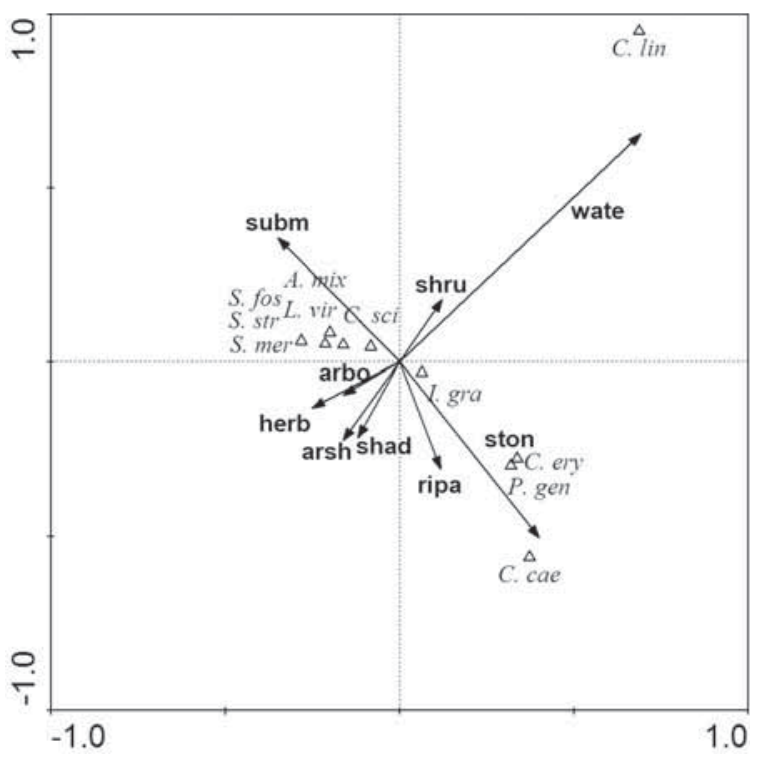

Figure 2. Odonata species and environmental variables ordination obtained by Canonical Correspondence Analysis (CCA) of the 1999 data. Ordenación de las diferentes especies de libélulas y de las variables ambientales obtenida mediante un Análisis Canónico de Correspondencias (CCA) de los datos de 1999.

\section{DISCUSSION}

After the impoundment of the North Anna River in Virginia, USA, Voshell \& Simmons (1978) recorded a reduction dragonfly species from 24 to 13 . In the present study, after the impoundment of the Guadiana River in Portugal, the species richness was not modified. However, the composition was different. A. mixta, C. caerulescens, C. scitulum, S. foscolombei, S. meridionale and $S$. striolatum were no longer sampled. The preference of dragonfly species for lotic or lentic ecosystems may have influenced this new composition. The impoundment of a river creates an ecosystem that is similar to a lake, modifying chemical and physical characteristics of the water, such as dissolved oxygen, conductivity and current velocity (Hecky et al., 1984; Thornton et al., 1990; Avakyan \& Podol'skii, 2002). Askew (2004) reported that dragonfly species such as $A$. parthenope and $O$. coerulescens can show preferences for lentic ecosystems, whereas others, such as $C$. caerulescens, can prefer lotic ecosystems. A. parthenope and $O$. coerulescens were recorded exclusively after the construction of the reservoir when the river was like a larger lake; 
C. caerulescens was not sampled at all after the reservoir was constructed.

Apparently, there was a species overlap that occurred in rivers and streams by species that generally occur in ponds or lakes. Beyond modifications in the characteristics of the water, the construction of the Alqueva Reservoir also modified the structure of the vegetation. Before the impoundment of the river in 1999 , the riparian vegetation was mechanically removed; this strongly altered the shoreline characteristics of the river.

Habitat structure, such as marginal vegetation, is very important for all dragonfly species (Niba \& Samways, 2006). However, some species, such as Sympetrum spp., can be more affected. This species has a longer pre-reproductive phase and needs high quantities of resources, such as food obtained mainly from riparian areas (Corbet, 1999; Kadoya et al., 2008). At site 36, where we recorded $S$. fonscolombei, $S$. meridionale and $S$. striolatum, there was an marked reduction in the shoreline vegetation, and these species were no longer recorded. A strong reduction in the abundance of Sympetrum spp. also was recorded after the construction of a dike (Cannings \& Cannings 1998). According to the authors, modifications in the structure of the habitat negatively affected the abundance of this species. On other hand, C. erythraea exhibited high tolerance in the present study.

$C$. erythraea's abundance increased at the sites with reduced shrubby and arboreous vegetation. The positive correlation between human disturbances and $C$. erythraea has already been recorded in the S'Albufera Natural Park in Mallorca, Spain (Sato \& Riddiford, 2007) and the Kogelberg Biosphere Reserve in the Western Cape Province of South Africa (Grant \& Samways, 2007). This species exhibits rapid development, which contributes to its survival in disturbed sites (Suhling et al., 2004). T. annulata was also tolerant, but only in the sites with reduced riparian vegetation. Males of this species show territoriality. and degraded sites decrease the risk of disruption by rival males (Schenk et al., 2004).

We concluded that, from 1999 to 2003, after the impoundment of the Guadiana River, the dragonfly species richness did not change, pos- sibly because of species overlap, yet the species composition was modified. Changes in marginal vegetation after the construction of the reservoir may have had an important influence on the change in dragonfly species composition.

\section{ACKNOWLEDGEMENTS}

The first author is grateful to the CAPES (2096/07-2), which provided financial support.

\section{REFERENCES}

ASKEW, R. R. 2004. The Dragonflyof Europe, $2^{\text {ond }}$ ed. England. Harley Books. 308 pp.

AVAKYAN A. B. \& S. A. PODOL'SKII. 2002. Impact of Reservoirs on the Fauna. Water Resources, 29: 123-132.

CANNINGS, R. A. \& S. G. CANNINGS. 1998. Odonata (Damselflies and Dragonflies). In: Assessment of species diversity in the Montane Cordillera Ecozone. I. M. Smith \& G. G. E. Scudder (eds.): 1-3. Ecological Monitoring and Assessment Network, Burlington, Canada.

CHOVANEC, A. \& R. RAAB. 1997. Dragonfly (Odonata, Insecta) and the ecological status of a newly created wetland-examples for long term bioindication programmes. Limnologica, 27: 381-392.

CHOVANEC, A. 2000. Dragonfly (Insecta: Odonata) as indicators of the ecological integrity of aquatic systems-a new assessment approach. Verh. Internat. Verein. Limnol., 27: 887-890.

CHOVANEC, A. \& J. WARINGER. 2001. Ecological integrity of river-floodplain system-assessment by dragonfly surveys (Insecta: Odonata). Regulated Rivers: Research and Management, 17: 493-507.

CLAUSNITZER, V. 2003. Dragonfly communities in coastal habitats of Kenya: indication of biotope quality and the need of conservation measures. Biod. and Conserv., 12: 333-356.

CORBET, P. S. 1999. Dragonflies: Behavior and Ecology. New York, USA: Cornell University Press. $829 \mathrm{pp}$.

CORBET, P. S. 2006. Forests as habitats for dragonfly(Odonata). In: Forests and dragonflies. A. C. Rivera (ed.): 13-36. Pensoft Publishers, Sofia, Bulgaria. 
D'AGUILAR, J. \& J. L. DOM MANGET. 1998. Guide des libellules d'Europe et d'Afrique du Nord. Paris, France: Delachaux et Niestlé. 463 pp.

GOPAL, B., P. K. GOEL, K. P. SHARMA \& R. K. TRIVEDY. 1981. Limnological study of a freshwater reservoir, Jamwa Ramgarh (Jaipur). Hydrobiologia, 83(2): 283-294.

GRANT, P. B. C. \& M. J. SAMWAYS. 2007. Montane refugia for endemic and Red Listed dragonflyin the Cape Floristic Region biodiversity hotspot. Biod. and Conserv., 16: 787-805.

HECKY, R. E., R. W. NEWBURY, R. A. BODALY, K. PATALAS \& D. M. ROSENBERG. 1984. Environmental Impact Prediction and Assessment: The Southern Indian Lake Experience. Can. J. Fish. Aquat. Sci., 41: 720-732.

KADOYA, K., S. SUDA, Y. TSUBAKI \& W. I. IZUMI. 2008. The sensitivity of dragonflyto landscape structure differs between life-history groups. Landscape Ecol., 23: 149-158.

NIBA, A. S. \& M. J. SAMWAYS. 2006. Development of the concept of 'core resident species' for quality assurance of an insect reserve. Biod. and Conserv., 15: 4181-4196.

SAMWAYS, M. J. \& N. S. STEYTLER. 1996. Dragonfly (Odonata) distribution patterns in urban and forest landscapes, and recommendations for riparian management. Biol. Conserv., 78: 279-288.

SATO, M. \& N. RIDDIFORD. 2007. A preliminary study of the Odonata of S'Albufera Natural Park, Mallorca: status, conservation priorities and bio- indicator potential. J. Insect Conserv., 12(5): 539548.

SCHENK, K., F. SUHLING \& A. MARTENS. 2004. Egg distribution, mate-guarding intensity and offspring characteristics in dragonfly(Odonata). Anim. Behav., 68: 599-606.

SHANNON, C. E. \& N. WEAVER. 1963. The mathematical theory of communication. University of Illinois Press. Illinois, USA. 144 pp.

SUH, A. N. \& M. J. SAMWAYS. 2001. Development of a dragonfly awareness trail in an African botanical garden. Biol. Conserv., 100: 345-353.

SUH, A. N. \& M. J. SAMWAYS. 2005. Significance of temporal changes when designing a reservoir for conservation of dragonfly diversity. Biod. and Conserv., 14: 165-178.

SUHLING, F., K. SCHENK, T. PADEFFKE \& A. MARTENS. 2004. A field study of larval development in a dragonfly assemblage in African desert ponds (Odonata). Hydrobiologia, 528: 75-85.

TER BRAAK, C. J. F. 1986. Canonical correspondence analysis: a new eigenvector technique for multivariate direct gradient analysis. Ecology, 67: 1167-1179.

THORNTON, K. W., L. B. KIMMEL \& E. P. FORREST. 1990. Reservoir limnology: ecological perspectives. Wiley-Interscience. New York, USA. $256 \mathrm{pp}$.

VOSHELL, J. R. \& G. M. SIMMONS, 1978. The Odonata of a new Reservoir in the Southeastern United States. Odonatologica, 7(1): 67-76. 